\title{
EVALUATION OF THE POTENTIAL OF SCENTED GERANIUM PLANT (PELARGONIUM ROSEUM) TO UPTAKE AND ACCUMULATE LEAD
}

\author{
Majid Mahdiyeh \\ Mohammad Reza Sangi \\ Malek Soleimani \\ Abolfazle Tagavi \\ Arak University, Iran
}

\begin{abstract}
The major objective of this investigation was to evaluate the potential of scented geranium plant, Pelargonium roseum to uptake and accumulate lead under greenhouse conditions. Plants were grown in an artificial soil system and exposed to a range of lead concentrations $\left(0-2500 \mathrm{mg} . \mathrm{L}^{-1} \mathrm{~Pb}(\mathrm{NO}) 2\right)$ in over a 14 day treatment period. The results showed that the uptake and accumulation of lead in shoot and root followed a similar trend. The highest amount of lead accumulation was detected at $2500 \mathrm{mg} \cdot \mathrm{L}^{-1}$ lead nitrate in the culture solution that was $86566.68 \pm 7864 \mathrm{mg} \cdot \mathrm{kg}^{-1} \mathrm{DW}$ for roots and $4416.04 \pm 502.27 \mathrm{mg} \cdot \mathrm{kg}^{-1}$ DW for shoots. The linear pattern of uptake suggests the involvement of both active and passive transport mechanisms for lead uptake. Finally, because the high concentrations of lead found in shoots of scented geranium plants has far exceeded $0.1 \%$ DW, Pelargonium roseum may be a new hyperaccumulator species for this metal and be used for phytoremediation industry.
\end{abstract}

\section{KEYWORDS:}

Phytoremediation, Lead hyperaccumulator, Scented Geranium, Pelargonium roseum

\section{INTRODUCTION}

Sites where soils are contaminated with heavy metals are commonly found as a result of activities such as metal mining and refining, specific industrial processes, or the long term disposal of wastes such as sewage sludge [1,2]. Elevated concentrations of heavy metals in soils may cause phytotoxicity, direct hazard to human health, indirect effects due to transmission through the food chain or contamination of ground or surface waters. 
Clean-up technologies have been developed for the removal of heavy metals [3], but often these are expensive or have some environmentally deleterious consequences. Soil washing techniques, both in situ and ex situ, aim to remove metals from soil, but have detrimental effects on their physical and biological properties and result in a waste product with a high metal content, which itself requires disposal.

Phytoremediation, the use of plants to reduce the risk associated with heavy metal contaminated soils, is now being actively investigated as a low-cost option that causes no deterioration in soil quality. The idea originated from the identification of hyperaccumulator plants, which can take up large amounts of heavy metals and accumulate high concentrations in their above ground tissues with no adverse effects on growth $[4,5,6]$.

Currently, the defining plant tissue concentrations for hyperaccumulation are $\mathrm{Cd}>100 \mathrm{mg} / \mathrm{kg} ; \mathrm{Co}, \mathrm{Cu}, \mathrm{Ni}, \mathrm{Pb}>1000 \mathrm{mg} / \mathrm{kg} ; \mathrm{Mn}, \mathrm{Zn}>10000 \mathrm{mg} / \mathrm{kg}$. However, plants with such a large accumulation of heavy metals typically produce relatively small amounts of biomass and have no economic value[7]. Thus identification of new plant species with a high biomass and a robust growth habit, coupled with ability to tolerate and accumulate multiple metals has become an important aspect of phytoremediation. Recently, Dan et al.[8] reported the ability of scented geranium plants(Pelargonium sp. 'Frensham')to tolerate and maintain normal metabolic processes, when exposed to various levels of cadmium, nickel and lead under greenhouse conditions. The overall objective of the current investigation was to evaluate the potential of the other species of the scented geranium plants, Pelargonium roseum, to uptake and accumulate metal pollutant lead from growth substrate. These plants have following characteristics that render them highly suitable candidate plant for phytoremediation:

(1)a dense foliage for sequestering high amounts of metals ions,(2)a prolific root system for absorption of metals from soils,(3)adaptability to a wide variety of soils with relatively low requirements for water and nutrients, and (4)economic return in the form of extractable essential oils from the harvested biomass.

\section{MATERIAL AND METHODS}

\subsection{Preparation of Test Material}

Scented geranium rooted cuttings (Pelargonium roseum) were used for all experiments in this study. Cuttings of scented geraniums made from greenhouse grown plants were rooted in plastic pots containing approximately $100 \mathrm{~g}$ of well-washed coarse Vermicolite. Plants (one plant in each pot) were placed in plastic saucers and 6 pots were used per treatment. The plants were grown in a greenhouse equipped with supplementary lighting $\left(16 / 8 \mathrm{hr}\right.$ photoperiod; 15klux) and controlled temperature $\left(20 \pm 2{ }^{\circ} \mathrm{C}\right)$ for $45 \mathrm{~d}$ with irrigation with half-strength Hoagland's solution [9]. 


\subsection{Metal Exposure}

During the treatment period (14 days), the rooted cuttings were treated with $50 \mathrm{~mL}$ of half-strength Hoagland's solution devoid of phosphates and sulphates, but supplemented with the metal salt. The metal treatments were provided as nitrate, as $0,1000,1500,2000$, $2500 \mathrm{mgL}-\mathrm{e} \mathrm{Pb}(\mathrm{NO} 3) 2$ and the $\mathrm{PH}$ of the metal solutions was adjusted to 6.0-6.5.The solutions were applied in the saucers and repeated at $24 \mathrm{hr}$ intervals, over the $14 \mathrm{~d}$ treatment period. Metal exposure was carried out on six individual plants per level of metal exposure, and the experiments were repeated at least twice

\subsection{Metal Analysis}

Plants from all the treatments were harvested at the same time, washed thoroughly with distilled deionized water, and divided into root and shoot biomass. Metal from the entire biomass was extracted using the closed teflon vessel method as described by Topper and Kotuby- Amacher [10]. Briefly, the tissue was cut into small pieces and oven dried at 80 ${ }^{\circ} \mathrm{C}$ for $2 \mathrm{~d}$. Oven-dried material was weighted and a sample of $1 \mathrm{~g}$ each was placed in teflon vessels. The plant material was digested by adding $30 \mathrm{~mL}$ of trace metal grade nitric acid(70\%), Merck, and the teflon vessels were placed in an oven overnight $(110$ ${ }^{\circ} \mathrm{C}$ ). The metal content in the extract was estimated using a flame atomic absorption spectrophotometry (AAS),Model Perkin-Elmer. Standard solutions were used to assess the concentrations of samples.

\subsection{Statistical Analysis}

Analysis of Variance (One-way ANOVA) was carried out using the Statistical software, SPSS, 10 to determinate if there were significant differences in metal accumulation as a result of metal treatments. Significant differences between the means assessed by Duncan test at $\mathrm{P}<0.05$.

\section{RESULTS}

Exposure of scented geraniums to various concentrations of lead induced morphotoxicity symptoms on the plants exposed to the higher levels(Figure 1).The symptoms were mostly observed on the mature leaves(at 12 day), which indicated signs of chlorosis and early senescence.

The uptake and accumulation of lead in roots of scented geranium plants increased linearly with increasing concentration of applied lead, although there is not significant difference between low and medium lead concentrations in $\mathrm{P}<0.05$. At the highest applied lead concentration $\left(2500 \mathrm{mgL}^{-1}\right)$ the amount of metal accumulation observed in the roots was $86566.68 \pm 7864 \mathrm{mg} \mathrm{kg}^{-1} \mathrm{DW}$ (Figure $2 a$ ), which was significantly higher than the lead contents measured in roots exposed to low and medium lead concentrations. 


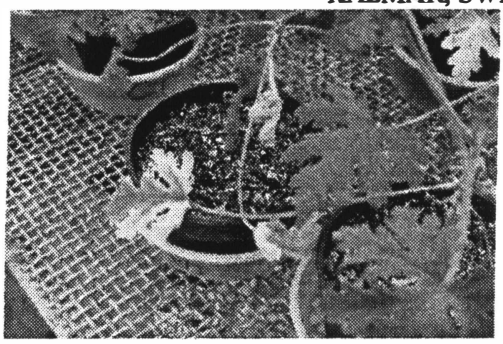

Figure 1. Morpho-phytotoxicity symptoms in scented geranium plants (Pelargonium roseum), following exposure to higher lead concentrations.

In the shoots of scented geranium plants, the uptake and accumulation followed a trend similar to the roots (Figure $2 b$ ).In general, lead content in shoots is less than roots in all treatments. In this tissue, difference between lead content in low lead concentration (1000mg.L) and control is not significant, also there is not significant difference between low and medium lead concentrations. The shoots of plants exposed to the highest lead concentration had the highest accumulation of lead (4416.04 $\left.\pm 502.2 \mathrm{mg}^{\mathrm{kg}} \mathrm{kg}^{-1} \mathrm{DW}\right)$.

\section{DISCUSSION}

The major objective of this investigation was to evaluate the potential of scented geranium plants (Pelargonium roseum) to uptake and accumulate lead. The significant finding of the present investigation was the demonstrated ability of scented geranium plants to accumulate and sequester elevated amounts of lead, within the 14 days treatment period. Additionally, the metal distribution pattern in the plant biomass indicated that the metal accumulation process was metabolically controlled.

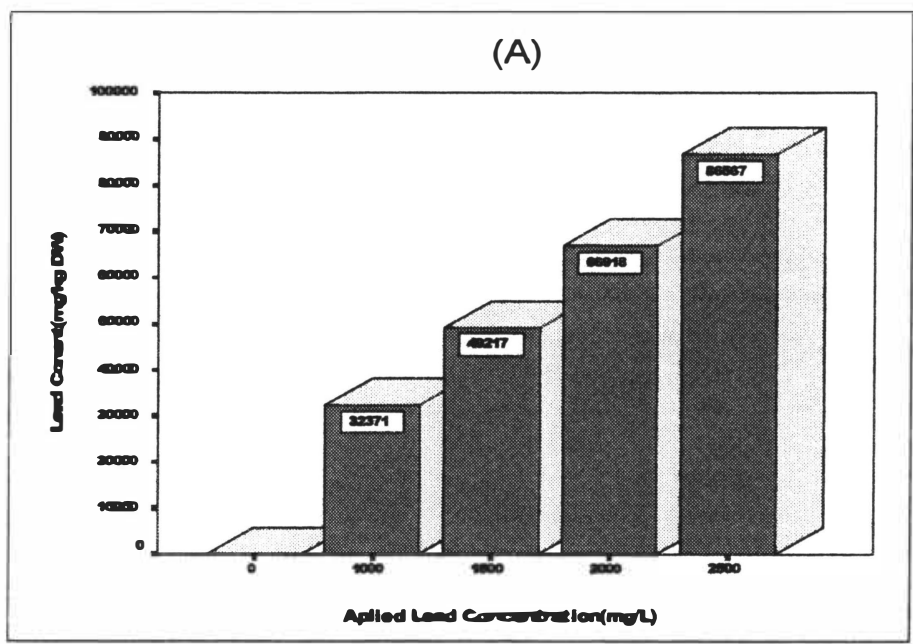




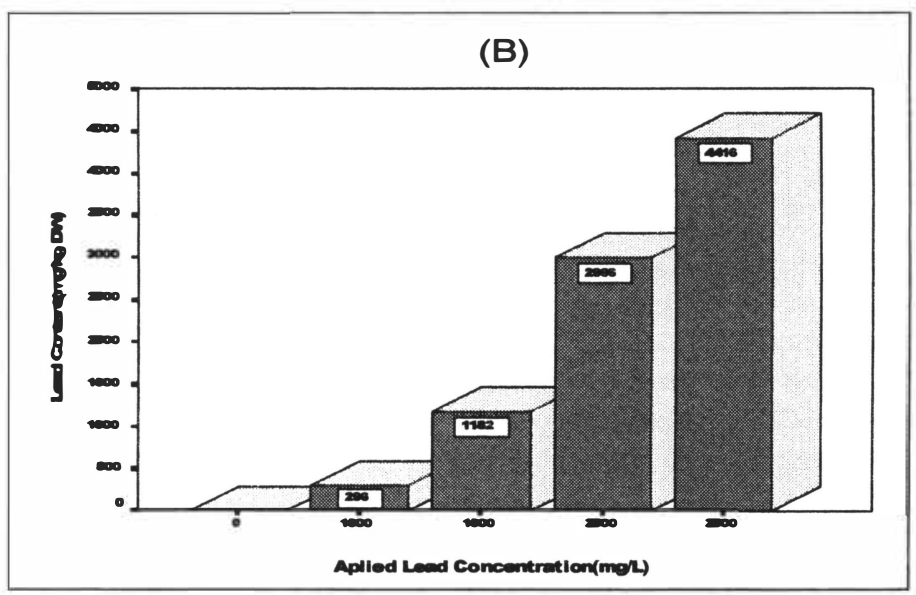

Figure2. Lead content in $\mathrm{mg} / \mathrm{kg} D W$ in root (A) and shoot(B) tissues in different Lead concentrations.

The lead content of the roots and shoots increased significantly in accordance with the rising supply of lead. The transport of lead to the shoots was directly proportional to the external lead concentration. Such pattern of uptake is an indication that the toxicity threshold has not been exceeded even at the elevated amounts of lead supplied, and the metabolic control of lead uptake is not lost. These findings suggest the involvement of both active and passive transport mechanism(s) for lead uptake. Since plants do not require lead for growth, they probably do not have transporters specialized for uptake of this heavy metal. Therefore, lead is likely to enter into plant cells via transporters for essential cations. Recent experiments support this hypothesis. For example, $N t C B P 4$, a tobacco transporters homologous to non-selective cation channel found in animal cells, was suggested to contribute to the entry of lead into plant cell since over-expression of the gene in tobacco resulted in accumulation of lead in the shoot [11], and calcium channel in bovine chromaffin cells has been shown to transport lead [12]. Based on these reports, we hypothesized that lead compete with other cations for entry into plant cells.

Most lead remained in roots and lead content in the root increased with concentrations of lead applied, but lead content in shoots did not. Lead transfer from root to shoot remained low. These results suggest a tight barrier for lead translocation. The higher lead content found in the roots of metal accumulators is highly dependent on at least two components, namely: sequestration and/or translocation.

Krishna Raj et al.[13] suggested that lignification of cell walls, and formation of metallignin complexes, might be one primary mechanism of lead tolerance and uptake in the roots of scented geranium plants exposed to lead. Hardiman et al.[14] have suggested that 
the cadmium ions enter the stele through leakage and their translocation rate to shoot is dependent on the root concentration. We suggest that in the case of lead in scented geranium plants a similar scenario exists, wherein the amount of metal accumulation in the shoots was proportional to the one transported to shoots. The high concentrations of lead found in the shoots of scented geranium plants has far exceeded $0.1 \% \mathrm{DW}$ which is considered as a standard for defining lead

In the present investigation we have demonstrated the lead accumulation potential of Pelargonium roseum. This, along with earlier reports on the hyper-tolerance [8] and lead accumulation in Pelargonium sp. 'Frensham' [13], indicates the efficacy of species of this plant in site remediation. Under this circumstance, the accumulation of lead in scented geranium plants is of major importance, offering both an efficient plant species for phytoremediation and a unique model system for the study of physiological stress response

\section{ACKNOWLEDGEMENT}

This research was supported by a grant from Arak University. We thank Mr. Hamid Reza Mirdavoodi (Agricultural Jahad of Arak), Mr. Seyed Norollahe Mousavi (Department of Matematics) and Mr. Majid Rajabi (Graduate student of biology, Arak University) for their assistances in conducting this research.

\section{REFERENCES}

[1] Alloway, B. J.(Ed), 1995, Heavy Metals in Soils.Glasgow, Blackie Academic and Professional.

[2] Ross, S. M. (Ed) 1994, Toxic Metals in Soil-Plant Systems. Chichester, John Wiley and Sons.

[3] Martin, I. And Bardos, P., 1996, A Review of Full Scale Treatment Technologies for the Remediation of Contaminated Soil. Richmond, EPP Publications.

[4] Baker, A. J.eM., Reeves, R. D. and Hajar, A. S. M., 1994, Heavy metal accumulation and tolerance in British populations of the metallophyte Thlaspi caerulescens J. and C. Pres\&(Brassicaceae), New Phytol. 127, 61-68.

DO1: https://doi.org/10.1111/j.1469-8137.1994.tb04259.x

[5] Chaney, R. L.e, Malik, M.e, Li, Y. M. ,Brown, S. L., Brewer, E. P., Angle, J. S., and Baker, A. J.eM., 1997, Phytoremediation of soil metals. Curr. Opin. Biotechnol., 8, 279-284.

[6] Brooks, R. R., 1998, Plants that hyperaccumulate Heavy Metals: Their Role in Phytoremediation, Microbiology, Archaeology, Mineral Exploration and Phytomining, Wallingford, Oxon, U.K., New York, CAB International. 
KALMAR ECO-TECH'03

Bioremediation and Leachate Treatment

KALMAR, SWEDEN, November 25-27, 2003

[7] Gleba, D., Borisjuk, N. V.,Borisjuk, L., Kneer, R., Poulev, A., Skarzhiskaya, M., Dushenkov, S., Logendra, S., Gleba, Y. and Raskin, I., 1999, Use of plant roots for phytoremediation and molecular farming, Proc. Natl. Acad. Sci. 96, 5973-5977.

DOI: https://doi.org/10.1073/pnas.96.11.5973

[8] Dan, T. V., KrishnaRaj, S. and Saxena, P. K., 2000, Metal tolerance of scented geranium (Pelargonium sp. Frensham): effects of cadmium and nickel on chlorophyll fluorescence kinetics, Int. J. of Phytorem. 2(1), 91-104.

DOI: https://doi.org/10.1080/15226510008500032

[9] Hoagland, D. R. and Arnon, D. I., 1938, The water culture method for growing plants without soil, UC College of Agriculture, Ag. Exp. Station. Berkley, CA, Circular 347 , pp. 1-39.

[10] Topper, K. and Kotuby-Amacher, J.:1990, Evaluation of a closed vessel acid digestion method for plants analyses using inductively coupled plasma spectrometry, Commun. Soil Sci. Plant Anal. 21, 1437-1455.

DOI: https://doi.org/10.1080/00103629009368315

[11]Arazi, T., Kaplan, B., Fromm, H., 2000, Cyclin-nucleotide and Ca/calmodulinregulated channels in plants: targets for manipulating heavy-metal tolerance, and possible physiological roles, Biochem. Soc. Transactions 28: 471-475.

[12] Tomsig, J. L., Suszkiw, J. B.,1991, Permeation of Pb through calcium channels:fura-

2 measurements of voltage- and dihydropyridine-sensitive $\mathrm{Pb}$ entry in isolated bovine chromaffin cells. Biochim. Biophys. Acta 1069: 197-200.

DOI: https://doi.org/10.1016/0005-2736(91)90124-Q

[13] KrishnaRaj, S., Dan, T. V. and Saxena, P. K.:2000, A fragrant solution to soil remediation, Int. J. of Phytorem. 2(2), 117-132.

DOI: https://doi.org/10.1080/15226510008500034

[14] Hardiman, R. F., Jacoby, B. and Banin, A.:1984, Factors affecting the distribution of copper, cadmium and lead and their influence upon yield and $\mathrm{Zn}$ content in bush beans(Phaseolus vulgaris), Plant and Soil 81, 17-27.

DOI: https://doi.org/10.1007/BF02206890 